\title{
Patterns of Power Relations: Sabotage, Organisation, Conformity and Adjustment
}

\author{
Jeffrey Harrod, University of Amsterdam, Netherlands
}

\begin{abstract}
The purpose of this paper is to consider what findings an approach to work and production using different patterns of power relations could possibly yield concerning the responses to conditions which have emerged since the so-called 2008 crisis. Different theories and approaches to analysis of labour have different predictive outcomes from the material changes incorporated in recessionary conditions. The predictive outcomes of the power relations approach are contrasted with some contemporary trends. At the level of the political economy the approach allows a focus on the corporation and the power relations within and external to it. At the level of workplace, and based on preliminary and partial evidence for categories of power relations surrounding casual work, smaller enterprises, self-employment and corporate employment indicate that the expected dynamics of power relations are confirmed except in the case of corporate employment where responses are individual rather than organised. There is weak evidence of different organisations appearing within casual and precarious work. In general, however, it is argued that the approach provides greater flexibility and better possibilities for devising both policies and strategies to confront the current attempts to increase disciplinary power for the purpose of greater extraction.
\end{abstract}

\section{KEYWORDS}

Casual work, corporation, enterprise, models of political economy, power relations, work, selfemployment, social formations.

\section{Introduction}

The theme of this special issue of the Global Labour Journal 'Analysing Labour and the Crisis' contains an aggregate and description which do not necessarily fit different approaches to the aggregate 'labour' nor agree with many descriptions of the current situation as a 'crisis.' This paper addresses the problem of aggregating 'labour' but will view the crisis as a change in political economic circumstances over the last ten years which has a variety of effects on work and employment.

The study of work and labour and the authority which is involved in it has had a long history in western science and thought. In Politics Aristotle argued that the only condition in which work would not involve the authority or domination of master and slave or foreman and worker would be when there was automation or robotisation in which a shuttle could 'weave of itself' 
(Aristotle, Politics 1 iv) Since that time the various compartments into which the study of labour have been placed have either sought to emphasise the dominant-subordinate relationship or to disguise it. Thus in Marxist scholarship work, workers were subjected to a macro level domination of capitalists; in industrial relations trade unions negotiated with employers at the meso level; and Human Resources sought to eliminate subordination and domination at the micro level.

All these approaches, however, used the aggregate of labour and as a result as is well known the household work of women, the self-employed and even casual workers were not included. Marx described the marginal unemployed as lumpen proletariat, in industrial relations they did not appear at all, in Human Resource Management the individual contract has been twisted to include on work on demand (zero hour). Only the subject areas such as of sociology of work and anthropology and labour history started the study of the more discrete forms of power and authority surrounding work.

It was the short-comings of the conventional approaches and insights from other subject areas in the 1980's which inspired a different approach to work, labour and power in two free standing but linked volumes: R. Cox, (1987) Production, Power, and World Order: Social Forces in the Making of History New York: Columbia UP and J. Harrod (1987) Power, Production and the Unprotected Worker New York: Columbia UP. Part 1 of Cox (1987) Production, Power, and World Order: Social Forces in the Making of History outlined the approach which had been partially developed in the early 1970s by Robert Cox (Cox, 1971), (Cox, Harrod, 1974). Renewed interest in the approach has caused some revisions an updating (Harrod, 2006; Hurta, Knio and Ryner, 2009). The approach was used for a collection edited by M. Davies and M. Ryner, (2006) Poverty and the Production of World Politics: Unprotected Workers in the Global Political Economy. Palgrave: Macmillian.

The essence of the approach is its focus on power in production and that there will be different types, constellations and dynamics of such power. The argument within the approach is that the continued disaggregation of the world labour force using the criteria of occupation (schoolteacher, factory operative etc.), class (worker, entrepreneur), skills (skilled, unskilled), degree of employment (employed, unemployed, partially employed) and others, while having its uses, does not capture the dynamics of work and labour nor their importance in social and political change. The power relations approach also challenges categories made by income (waged, low-waged poor) as being power and work empty.

The power relations approach seeks different patterns of power relations surrounding production and disaggregates those that work on the basis of which pattern governs their work, returns and lives. For example, the proposition would not be challenged that the return to work and conditions of work are determined by a different power configuration in the case of a self-employed smallholder and a unionised worker in a large enterprise. Further, the power configuration can also mean that both the immediate demands, but more importantly, the attitude and world view will also be different. Thus to disaggregate the labour force by observable different patterns of power surrounding work is to illuminate not only the power relations but also the rationalities which sustain them and the changes which arise from them. In a subsequent section of this paper a brief description of eight patterns is provided.

Conceptually work, production, worker and power had to be defined. Production and work were less problematic and the standard notion is used that 'producers' are those engaged in production and work by expending energy for socially valued output. 
Power, as always, was more problematic - while industrial relations scholars often referred to 'power bargaining' other references were to the more vague 'authority in the work place' or the more realist 'domination and subordination in production'. For an approach which includes the whole of the world labour force any definition of power would have to include all of these.

The work of Foucault comes closer to making a useful distinction between different types of power. Power, for Foucault, is ubiquitous and creates domination and submission in a variety of institutions. There are, however, few references to disciplinary power set within work and production. He nevertheless recognises that the origin of disciplinary power was the need for it in production:

the other aspect of the conjuncture [other than the need to control nomadism, JH] was the growth of the apparatus of production which was becoming more and more complex. The development of disciplinary methods correspond to these two processes or rather no doubt to the new need to adjust to their correlation' (Foucault 1977, 218).

Equally important, however, was Foucault's separation between disciplinary power and sovereign power.

'the new type of power, which can no longer be formulated in terms of sovereignty, is I believe one of the great interventions of bourgeois society. It has been a fundamental instrument in the constitution of industrial capitalism and the type of society that is its accompaniment. This non-sovereign power, which lies outside the form of sovereignty, is disciplinary power' (Foucault 1980, 105).

Within the labour relations field - now called Human Resource Management or occasionally 'employment relations' - the relevance of Foucault did not go unnoticed and a number of articles applied the concept to that field (e.g. Townley, 1996). The notion of a decentred power inherent in the patterns of power approach, and the ubiquitous nature of power relations - for example in the household or surrounding the self-employed - is in conformity with Foucault's approach. His heuristic separation of sovereign power encourages the continued development of an approach which does not end with a discourse of production based classes, of sovereign power or in international relations of realism and hegemony. The individual focus in disciplinary power allows a pattern of power to develop without a conventionally defined class and the acceptance that there is a will to control or dominate confirms that each pattern has a dominant-subordinate relationship.

If disciplinary power does lend itself to patterns, constellations and configurations then it is precisely this power which was at the core of the power relations surrounding production. The failure of its appeal to sovereign power in terms of 'right' at the level of the state was precisely the reason for the development of the concept of the 'informal sector' (ILO, 1972) and in the power relations approach the 'unprotected worker' terminology (Harrod, 1987). The notion that disciplinary power had its own discourse to support it whether it is in the prison, asylum or factory also supported the idea of a 'rationality' developed in conjunction with the power relations to support their effectiveness.

Of course, this is not to accept all that Foucault argues nor all his ideas about power. To some extent a neo-materialist approach would move on from Foucauldian ideas as it does from Marx, and in doing so solves some of the problems raised by both their critics. There have also been 
convincing arguments made concerning the relevance of Bourdieu's habitus (Ryner, 2006) and 'public spheres' to the patterns of power approach (Davies, 2006).

The disaggregation using power criteria illuminates areas for policy, mobilisation and empowerment which are otherwise hidden by the aggregate labels used. For example, the much used concept of urban poor from the standpoint of power relations disguises that within the urban poor are a variety of patterns of power relations which yield different attitudes and demands from the designated population. The self-employed may be suffering from the power of their suppliers or direct users of their labour, those in small enterprises may not be able to redress the power of entrepreneurs, those that are casual workers and unemployed may find their major problem to be state institutions and policies, those that supply household services may seek to redress power within the household, those in family enterprises the dominant authority of the family. They may all be poor but their poverty is mediated by the immediate power within production so that policy or mobilisation appealing only to the level of income (urban poor) would miss many of important differences which are crucial to the success or failure of policy or mobilisation.

Research or approach to work and labour under changed conditions will only produce routine results when routine approaches and theories are applied to the situation. The current conditions are far from routine and need a different approach than those offered by traditional approaches such as Marxism, empiricism, and political and economic liberalism. The patterns of power approach may therefore be appropriate in these conditions.

The rest of this paper will examine this proposition first by outlining and illustrating the utility of the approach and then by selecting a few examples relevant to the theme of this edition.

\section{Patterns of Power Relations in Work and Production}

The power relations approach was essentially developed, with open admission to intuition and the use of ideal types, through the process of surveying the world labour force, with the purpose of seeking identifiable and distinguishable patterns of power relations surrounding work and production. Thus the power relations between an entrepreneur and a non-unionized employee are different from those between an indebted peasant and the moneylender or between those with a secure contract of employment and those casually employed.

The base uniformity of all the power relations is degrees of domination, subordination and authority within production. The differences in degrees of power and authority combined with different types of power holders and subjects of power create different patterns of power relations. These patterns are to be observed universally, thus the identification of them is not contingent upon country, region or other socio-political variables. The perspective in considering power patterns is global. The patterns described can be said to cover the bulk of the potential world labour force defined as persons between 15 and 64, which currently stands at approximately 4.5 billion, or 65 percent of the world population. The International Labour Organisation (ILO) and World Bank definitions of labour force and economically active populations are not suitable as they exclude for example 'homemakers and other unpaid caregivers and workers in the informal sector' (World Bank, 2014).

The eight patterns discussed in this article are not exhaustive and do not cover the entire global labour force. For example, forced labour or 'slavery-like practices' are estimated by the ILO to involve 21 million people (ILO, 2012). The power relations would certainly indicate a unique 
pattern of relations. However, such a pattern would therefore cover 0.5 per cent of the world labour force and cannot be considered to be critical to the viability of any known social formation, although at the sectoral level the situation would change. Research into such a social formation would have to establish if the sector was important and then if the 'slave' pattern was important to the sector. Unpaid family work might also qualify as a different pattern because the authority in the enterprise is, as the enterprise pattern, based on the power to withhold work but is bolstered by the family structured often, but not always based, on patriarchy. In short, authority in a family-owned enterprise is not necessarily predominately the ability to withhold livelihood.

\section{EIGHT PATTERNS OF POWER RELATIONS}

Currently eight strategic and important patterns can be discovered by considering the world labour force, the status of employment, the occupational changes and the changes in structures of different political economies. It should be emphasized that these patterns could be named 1-8 or A to $\mathrm{H}$ but for purpose of image and identification an attempt has been made to use words which help capture the core power relationship or the most important persons, groups and organizations in the pattern. The current patterns may be referred to as tripartite, corporate, state corporatist, peasant, casual, enterprise, self-employed and household.

A sketch of each is provided here:

tripartite - a three part power pattern between state agencies, worker organisations and employers.

corporate - power relations between management and producers within a corporation with no (or weak) worker organisation with external links.

state corporatism - the relationship between the management of state agencies and civil servants and others directly covered by state employment relations.

enterprise - power relations between owners - managers in smaller enterprises and the individual employees.

casual - the power relations between users and providers of labour are usually fragmented by space or time thus allowing for no meaningful occupational security.

self-employed - power relations are between supplier, competitor, regulator and customer and a single producer or producing household (in the case of land-owning cultivator) who does not formally employ.

household - power relations are found in the allocation and distribution within a household - usually family.

peasant - power relations between renting cultivator and land-owner. 
Each of the patterns is dynamic, that is, power relations are dynamic and the patterns may be transformed or eliminated. More importantly, persons within one pattern may find themselves moving from one pattern to another and may be in several patterns at the same time.

For example, the power relations surrounding the work of a self-employed person, defined as someone producing without employing other people, has four facets. The work and production of the self-employed person is altered by the suppliers of needed materials or services, the regulations of the conditions of production which are often state agencies, the customers and the competitors. The level of the return to work is determined by the nature of the engagement of the self-employed person with these powers. If, however, someone is employed by the self-employed person then a new actor in the power relations is introduced and the pattern becomes more typical of a small enterprise - and the previously self-employed becomes an employer with power over the employee. The fourfaceted pattern has now become a five-faceted pattern and the roles and attitudes of the persons involved will change.

A visual expression of the power relations and their transformations is seen in the illustrations below.

Illustration 1: Self-Employment and Enterprise Power Patterns

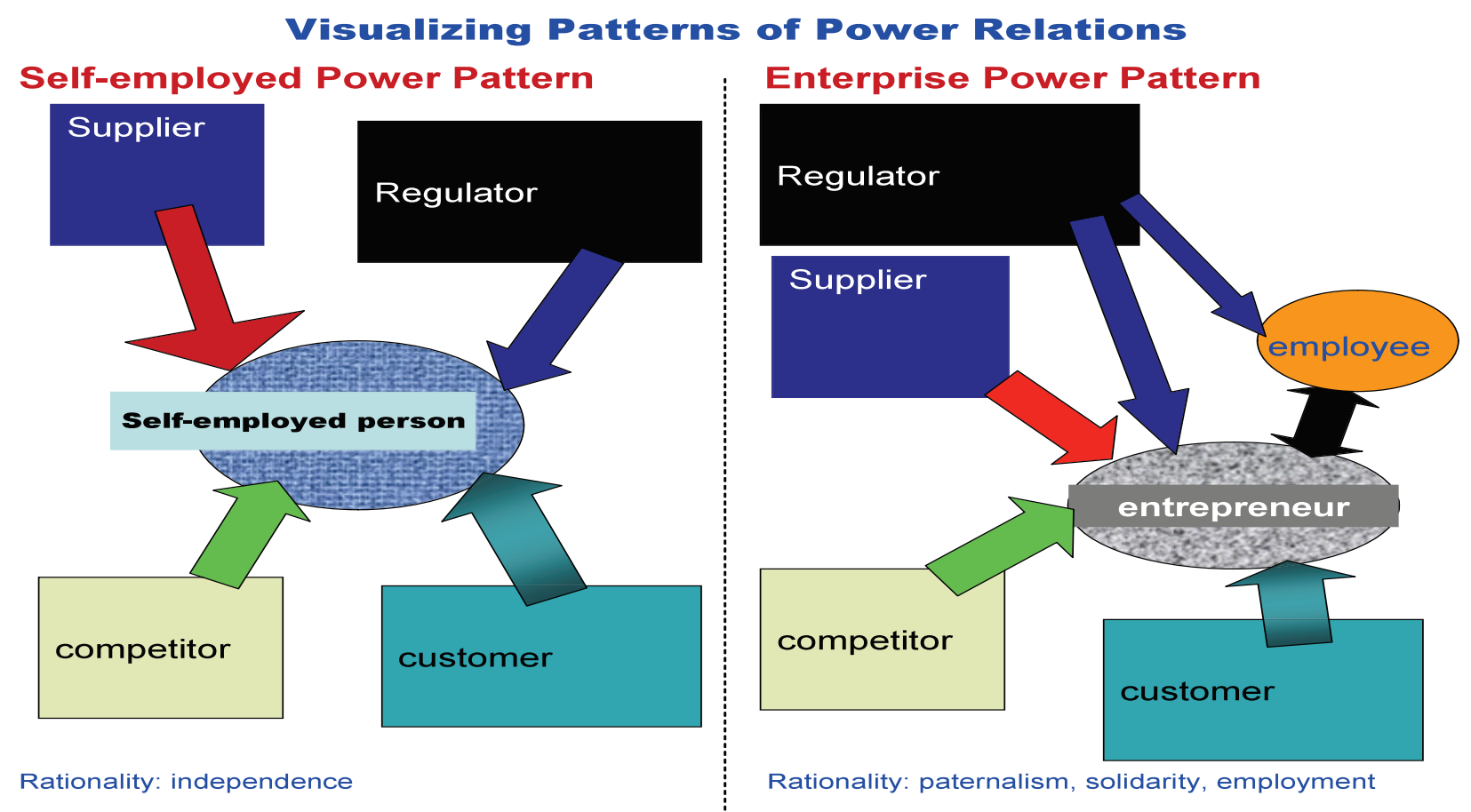

In Illustration 1, the self-employment pattern has been changed by the addition of an employee and the conversion of the independent self-employed person to an owner-manager or entrepreneur. The internal rationality also changes to cope with the justification of employment and the usually different rewards from it. 


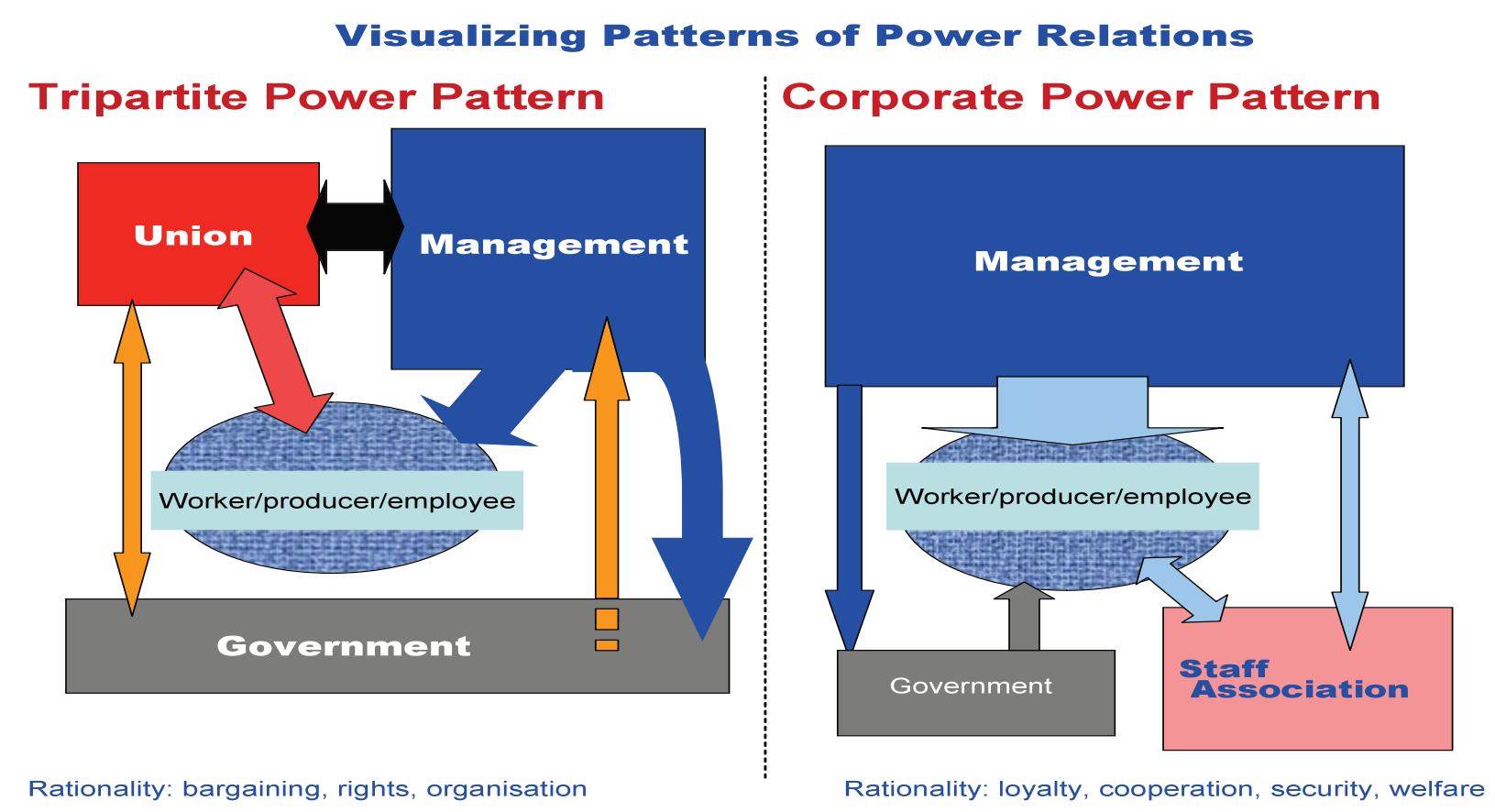

In Illustration 2, the essential change is that the union becomes an internal part of the corporate power relations despite it being a broader external force. The corporate approved 'staff association' when it associates with an external union or declares autonomy in bargaining thus transforms corporate power relations into tripartite power relations. It would be convenient if the size of the blocks in the illustration were indicators of power. This is not possible without very intensive research and defining with great precisions the criteria of power in detail. However, it is clear that in the 'Tripartite Pattern' unions are more powerful than in the Corporate Pattern and this is indeed represented by the different sizes of the blocks.

\section{THE SOCIAL FORMATION}

From the standpoint of social and political change it is also argued that the power relations in production are the source of 'rationalities' ideologies, world views, or institutionalized practices which enable, disguise or mitigate psychologically the acceptance of the inherent authority, domination and the inequalities within, and resulting from, the power relations. The strength of such rationalities and the internalization of them by subordinate producers affects the nature and direction of change originating in these relations. The development of world views or counterrationalities and the political action which they precipitated or determined are then an essential part of social change.

In the global political economy there are recognisable clusters of these patterns. Some of the patterns are dominant in that the groups and actors within them and the dynamics of their particular power relations substantially affect the nature of other patterns. Subordinate patterns are led by events and outputs from the dominant patterns. The combination of the dominant and subordinate patterns in any identifiable cluster is considered as a distinct political economy or social formation which may or may not be coterminous with an existing nation state. Thus the power relations 
between important trade unions and corporations clearly affect, in terms of wages, conditions, of work and labour law, those people in other patterns such as the self-employed, unorganized small enterprise worker and small-scale farmers.

In the patterns of power relations approach, the macro level of capitalism as an unvarying universal is not accepted. The power of capital and capitalists is organised through the position they hold in the various patterns, the attempted manipulation of the patterns and the role the patterns play within any social formation. In the illustration below a contemporary and common distinction between the three models of typical social formations is used: the Anglo-American model, the European Social Partner and the Asian Development Model. These are used in heuristic fashion and their use is not intended to endorse either their labels or indeed their existence.

\section{Illustration 3: Power Patterns and Models of Political Economy}

\section{Visualising Power Patterns and Models of Political Economy}

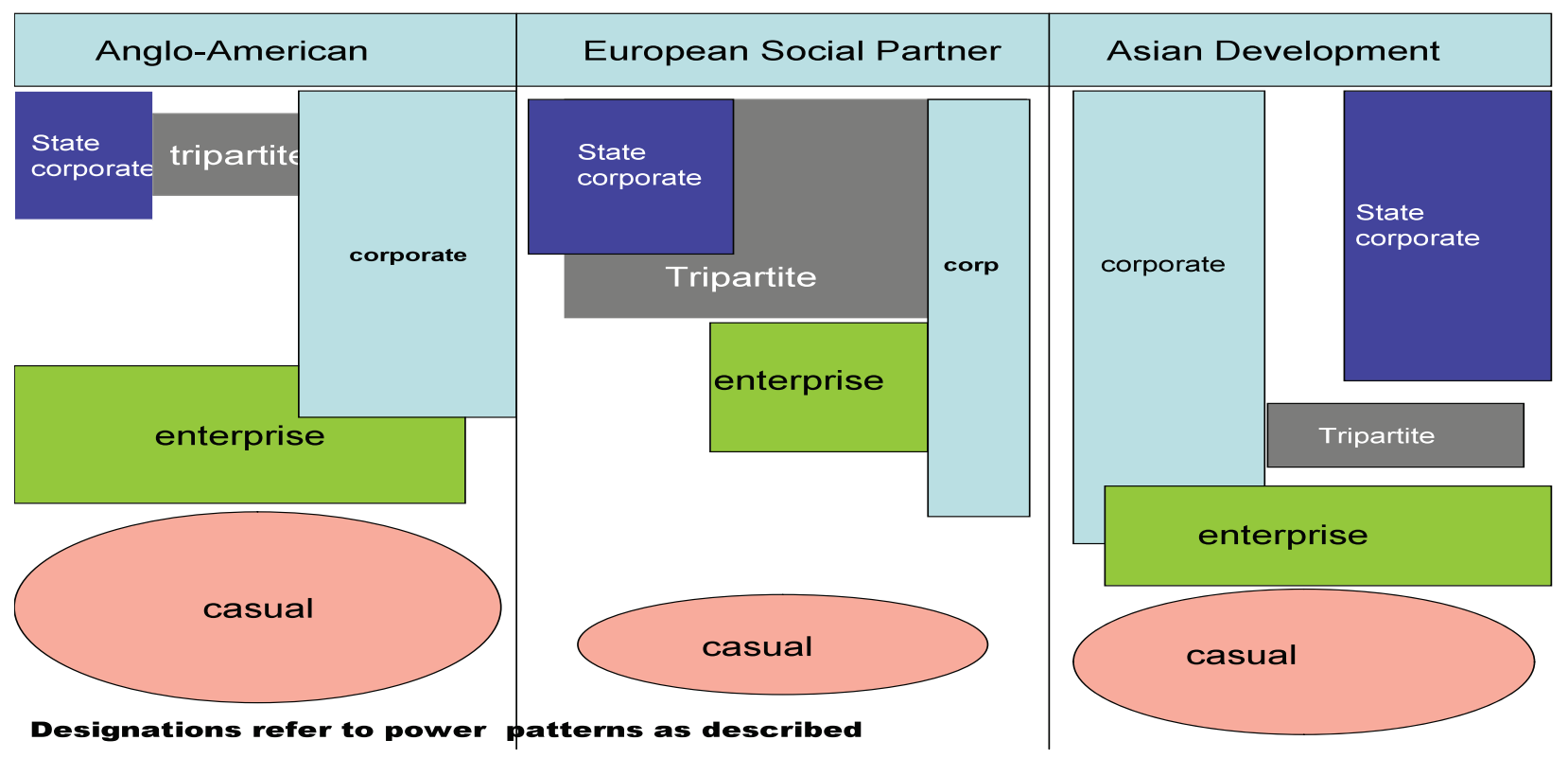

In Illustration 3, clusters of power relations are provided in approximations of power and size. Power is represented on the vertical axis. Size in terms of the number of persons covered is represented by the area of the figures in the illustration.

Thus the state-corporatist pattern containing state bureaucracies is more powerful and important in the Asian Development Model than in the Anglo-American model, and there are greater numbers of casual and precarious workers in the Anglo-American model than in the European Social Partner Model.

This is a stripped down account of an approach to society and thus to world politics which begins with power at its lowest and most immediate level - at the workplace. It is not the purpose here to present the details and arguments in support of such an approach but rather to introduce the idea of the need to revise current perceptions and show what such an approach might yield for the purpose of political analysis. 


\section{Rationalities, Internal and Internal and External Dynamics}

The patterns of power relations are complex, but for the purposes of this paper five of the elements of each pattern to be considered will be described - the internal power dynamics, the internal and external rationalities, the external relations which support the pattern and the expected transformation path from one pattern to another.

\section{INTERNAL POWER DYNAMICS}

As noted in the brief descriptions above within each pattern there is a core relationship often easily identified in a person or institution. For conventional analysis this core power relationship is often indicated in the name of the pattern - thus 'tripartitism' means the core power relationship between government, employer and union, or 'enterprise' between owner-manager and employee, and 'household' between the holder of authority in the household and those to which tasks and income are allocated.

This means that in each pattern degrees of dominance and subordination can be observed. These relationships are core but each pattern has more complexity than the binary dominancesubordination of the core and in many patterns there are multiple sources of competing power.

\section{EXTERNAL POWER DYNAMICS}

The patterns do not exist even as ideal types in isolation from each other. They are parts of complexes of patterns as noted above which may make a distinct model of a social formation or political economy. In discussing the impact of conditions associated with the recent financial crisis on these patterns the external relations to them are usually more important than the internal power relations.

\section{RATIONALITIES}

There are two levels of rationalities. At the macro level are those which could be considered as societal and, perhaps in the contemporary world, global, and those which are discrete to the specific pattern of power relations. A macro rationality which is global in scope forms the framework in which discrete forms of power relations develop. The sources of macro rationalities are religion, governance, economy and biology and each can be associated with the 'organizations' of the church, the state, the corporation and the household. For Cox $(1987,25)$ a rationality is a 'collective mentality' a 'typical way of perceiving and interpreting the world' held by different social groups within different forms of power relations which sustain the continued existence of the form. But rationalities are also mental constructs which attempt to induce an acceptance of the exercise of power which otherwise might be unacceptable. This is the emphasis that I placed upon a similar use of the concept (Harrod 1987, 33). Rationalities explain the unexplainable, excuse the inexcusable and offer a refuge for those who do not wish to deal with or confront power - often by denying its existence.

Similar concepts to this use of 'rationality' have been used in the analysis of almost all those who have set out to consider the nature of society and governance. Thus what I have called a rationality could be seen also in Weberian unauthentic legitimisation, Foucauldian 'governmental 
rationality' or in the concept of a dominant discourse. Likewise, it may be the internalisation of the norms of ruling class governance as in Gramscian hegemony, or the Marxist superstructure. Hans Morgenthau gave no name to his power disguising-construct preferring to call it that 'something'. 'What is actually aspiration for power, then appears as something different, something that is in harmony with the demands of reason morality and justice' (Morgenthau 1967, 119).

The discrete rationalities which are part of a pattern of power relations sustain or alter the allocation of power and distribution. Examples of the more discrete rationalities are the doctrine of divine right of landowners in the peasant pattern of power relations, of harmony within diversity in corporate or state corporatism patterns, or paternalism and the 'working boss' ethic in the enterprise pattern, and the 'woman's work' rationality for inequality in the household.

In different patterns of power relations different uses of macro rationalities can be observed. The household pattern of power relations relies on both patriarchy and religious rationalities to ensure different allocation and returns to work for women members of the household. The justification of landownership for indebted, rack-rented peasants draws on the notion of rule by divine right. The rationality which governs relations within large enterprises relies heavily on a discrete idea of corporate loyalty.

The concept of consciousness is used here as an awareness, realization or cognizance at the individual level of the power relations and their outcomes. Consciousness need not be 'oppositional' for at the individual level the rationalities may be a satisfactory answer to perceived inequities (Mansbridge and Norris, 2001). However, collective action within any of the patterns is predicated on consciousness of the power relations. Without such a consciousness there would be no worker organizations in the enterprise pattern, institutionalization of them as unions in tripartite, producer cooperatives in self-employment, mutual aid and local associations in household and chiliastic events in the peasant pattern.

\section{TRANSFORMATION TRAJECTORIES}

A pattern is transformed into another pattern by a change in the power relations. There is no developmental or hierarchical trajectory although some patterns contain within them more powerful entities than others. Thus when a union severs its external connections to a corporation and becomes a staff association then the pattern moves from a tripartite to a corporate pattern. When a cultivator escapes rent payments and produces directly for a market the pattern governing the production changes from peasant to self-employment. Often individual participants, workers or producers leave one pattern for another. Substantial and broader changes may eliminate a pattern entirely. Of more importance is the transformation of the social formation. Since the launching of neoliberalism as a governing ideology in the early 1980s there has been a clear attempt to remove the tripartite pattern from its position of dominance in favour of a social formation with the corporate pattern in the strategic position.

\section{Patterns of Power Relations Since 2008}

This special issue is devoted to 'Labour and the Crisis'. For the purposes of this paper the 'crisis' emerging in 2008 can be considered as lower or negative economic growth, unemployment, 
decreased economic activity, and continuing decline in real wages, pensions and state-derived social benefits.

In the framework of the approach presented the first avenue for research and investigation is associated with the change in the configuration of patterns in the social formation. As noted above, since the 1980s, the social formations of core and powerful political economies are in transition from one in which the tripartite pattern was dominant to one in which the corporate pattern was dominant. This has meant an increase in the size (numbers covered) in causal, self-employment forms and a destabilisation of the enterprise pattern.

This process has been ongoing for several decades and the 2008 financial crisis was one manifestation amongst many others. This approach would indicate that there is not a 'crisis' of power and control. To the contrary the elites in the corporate pattern have emerged stronger than ever since state financial flows to corporate entities have been institutionalised. The ongoing contradiction, however, is the strength of the rationality which cements power relations based on the notion of 'market' which disguises power. This is a weak rationality and increasing opposition to it is part of the political and power dynamics of the transition from a social formation roughly in conformity with Marxist and neo-classical parameters to one of corporatism in which these parameters are either weak or do not apply (Harrod, 2006; Nitzan and Bichler, 2009).

The second avenue to apply the power patterns approach would be to consider changes within the patterns themselves. If the purpose must be to examine what has happened to the aggregation of labour since the so-called crisis of 2008 it would either have to be based on a specific case primary research or on any secondary sources which appear to be available. This is less than six years of research and it cannot be expected that the harvest of secondary level research is likely to be voluminous.

For this reason amongst others it is not possible to consider the impact of the factors of the crisis on all of the eight patterns enumerated above. Each of them has been affected either directly or indirectly by the material conditions since 2008. Some of these are well-known and substantially researched - for example the impact of austerity and unemployment on wage bargaining in the tripartite pattern or of increased youth unemployment on the household pattern. For purposes of illustration and because they are less the subject of conventional research four patterns will be briefly examined - the casual, self-employment, enterprise and corporate patterns.

\section{'CASUAL' PATTERN - WEAK ORGANISATION}

The power relations in this pattern are fragmented in time or space and are often individually based on an understanding between the hirer and the hired. Conventionally this pattern involves precarious or casual employment. This pattern may also include the proportion of the socalled unemployed who are still productively active.

Precarious work and casual work bring with them insecurity, instability and often psychological depression and desperation. There being no central pole of power there is no constructed rationality. The only weak rationality is that of an individual understanding which must be fulfilled on both sides. These populations often resort to millennialist movements and fundamental religion of all types. The individualist competitive nature for casual employment also raises a heightened sense of ethnicity and racial divisions (McDowell et al., 2009; Cooney, 2009).

This pattern of power has no determined transformational path, rather individuals leave the pattern when they secure stable employment or become routinely self-employed. Collective action as 
observed is usually based upon informal organisations protecting territory or practices which yield income. The organisations of groups or gangs which, for example, make sure that street vending territory remains within designated groups are commonplace.

The current changes have pushed more people into this pattern (ILO, 2010) and this in turn would indicate an increase in the adherents to millennialist and religious movements. The countries most affected by marginality, informality and precarious work have indeed shown growth in religious movements (Dushinsky, 2012). These developments would be predicted and expected from an analysis of the power relations.

Less expected, however, has been the weak but nevertheless present collective organisation of precarious and casual workers in recognisable social organisations. Choi and Mattoni (2010) show that there is a range of consciousness amongst casual and precarious workers starting from an absence (as would be predicted) to strategic consciousness leading to organisation. A similar range of organisations, possibilities and strategies has been found in sub-Sahara Africa (Lindell, 2010). Goldin, Rosenbaum and Eggleston (2006) report an increased presence of and acceptance amongst women precarious workers of non-governmental organisations, based on neighbourhood and other extra-work power relations criteria. Likewise in Japan, Allison (2012) sees 'extra-economic' networks arising from unemployed youths whose social activity is centred on 'net-café' (internet cafes). She sees this as 'recalibration' of social direction arising from the increased level of precarious work. In India, Agarwala (2007) notes that casual workers unlike those in more stable employment do not make demands on their immediate employers, but pressure the state for greater protection and open the channel for such workers to begin to act as a class.

Thus the impact of the crisis conditions has yielded in the casual pattern of power relations one expected result - the increase in the importance and the adherence to fundamentalist movements - and one indication not to be expected from the power relations - the beginnings of collective organisations aimed at materially improving conditions but not based directly on work and production factors. These latter findings may require a critique of the standard view that casual, 'informal' or precarious workers cannot be organised for the improvement of working conditions and returns.

As a footnote to this pattern which goes beyond the scope of this paper, the increase in the number of people covered by the casual pattern of power relations, which also includes dependents, is a major indicator of increased social and political turbulence. The external aspects of these relations have always resulted in the adherence to radical and extreme movements. 'Marginals' have always been the foot soldiers of revolutionary change and have always been overlooked because of the perceptual prejudice in favour of the revolutionary potential of an established working class, as in Marxism, and a revolutionary peasantry, as in Maoism and $20^{\text {th }}$ century discourse on decolonialisation. (Harrod, 1987). When no attempt is made to stabilise work and income and ameliorate extreme material conditions, radical, extraordinary and populist parties and movements can be expected to gain momentum in all social formations in which the pattern exists.

\section{'SELF-EMPLOYED' PATTERN - ADJUSTMENT}

The self-employment pattern involves a single producer or producing household (in the case of land-owning cultivator) with power relations between supplier, competitor, regulator and customer. It should be noted that self-employment power relations contrasts with the standard 
definition of self-employment which includes employing entrepreneurs in an enterprise. Selfemployment corresponds here more to the ILO definition of 'own-account' worker.

The internal rationality of the self-employment pattern is that of independence, and sometimes escape, from the discipline of employment, or refuge from discrimination and workplace oppression. The macro rationality is the promoted belief of the 'entrepreneur' small business and enterprise creation within the market based capitalist ideology. Despite the positive ideological view of self-employment the power relations produce, in most cases, a condition of insecurity and of a producer 'embattled' by numerous predators.

As noted above the transformational process involving the self-employed pattern occurs when the self-employed become an employer in the enterprise pattern by engaging waged-labour.

The current conditions reduce the possibility of transformation via the enterprise route. While governments encourage 'start-ups' of self-employment, the policy of moving towards enterprise status is constrained by the increasing dominance in production of the larger units of the corporation. Further the extractive demands issuing from groups within in dominant patterns are increasing the power of the taxing state agencies.

The standard reaction to such a change in demands from one power actor in the complex is to attempt to off-load the income decline through adjusting prices of other actors. The general tendency to increased concentration means that suppliers are difficult to control - so much so that many self-employed find themselves captive to suppliers and rendered to be disguised outworkers of the supplier.

This leaves the possibility of increasing prices to customers which can only be done effectively by reducing competition from other self-employed. The self-employed in this respect correspond most closely to the capitalist competitive model and to rational choice actions.

The conflation of entrepreneurs in small enterprises with self-employment means that statistical evidence does not indicate how recession has affected the numbers within self-employment power relations. Recession conditions have, using the conventional definition, resulted in a significant decline in the OECD countries especially the USA and Japan. However, evidence that participants in self-employment power relations have declined is not available. One study of the European Union 15 (Milla, Congregado, Raman, 2009) showed that self-employed do not take employment when offered indicates that the internal power adjustments and the rationality to sustain non-employment may still prevail.

\section{'ENTERPRISE' PATTERN - CONFORMITY}

In the enterprise pattern, power relations are between owner-managers in smaller enterprises and individual employees. The internal rationality of the smaller enterprise rests on social loyalty with other workers (as distinct from a corporate loyalty) and respect and hierarchical input for the working and present owner-manager. The external or macro rationality is of the wider place of local and small enterprises within a product market framework. Under the impact of outsourcing and trade threats the local nature of the enterprise has become more important (see for example, Dufour, et.al 2006).

The power dynamics between owner-manager and employee are clearly under strain when there is increased unemployment and declining economic activity which may mean permanent or temporary lay-offs. It becomes more difficult for the owner-manager to deliver material benefits which might satisfy the notion of 'fair wages' and social cohesion of the enterprise. The material 
differences between owner-managers and employees become more visible. Enterprise income declines but owner-managers exploit their key position to maintain or even increase their material welfare while that of the employees declines. Against the loss of material benefits as rationality for continued stability within the enterprise the promoted vision of the enterprise under difficulty or under attack may reinforce the social loyalty while increased fear of redundancy mitigates any serious remedial action.

Increased alienation, militancy or dissatisfaction would, according to the dynamics of the power relations, result in the externalisation of grievances through joining or forming worker organisations - thus moving the enterprise power dynamics towards bargaining as in the tripartite or even a weak corporate pattern. Such a change would be expected to show up in increased trade union membership and/or increased union or union expansion statistics. There is indeed weak evidence that over the past four to five years this has occurred. Union membership which had been declining almost everywhere in the world has recently shown signs of stabilisation and in some countries of increasing. In Australia, for example, union membership rose by three percent in 2008. There is little data indicating that any increases or stabilization arise from smaller enterprises. There has also been some movement in sectoral organisation of small enterprises - thus, for example, workers in several small outsourcing enterprises in the cleaning sector in the Netherlands launched a successful campaign supported by a union federation to improve working conditions.

Nevertheless the pattern seems to be holding under recession conditions. Even under stringent conditions as in Bulgaria small enterprise workers report general satisfaction. Individuals are forced into precarious work or unemployment but any power pattern transformation towards effective bargaining is constrained.

\section{CORPORATE PATTERN - SABOTAGE}

The essential power relations in the corporate pattern is between management and employees within the organisation who have no or minimal external connections through unions and other organisations. The internal rationality of this pattern is corporate loyalty bolstered and promoted by material benefits of remaining within the corporation and serving it. The external rationality is the whole ideology of neo-liberalism, especially the need for corporate competition and success.

The impact of the recent changes has affected both the internal and external rationalities. The trend which has affected the internal rationality has been the spectacular increases in mergers and acquisitions. This undermines stable loyalty (Randals, 2001) as the goals of the core corporation fluctuate when dissimilar corporations are absorbed. While corporate social responsibility was supposed to develop loyalty to a larger social project (Spalding, 2007) the constant shifting of top managerial direction hinders such a development.

The external supporting rationality of neo-liberal competition, as already noted, has also weakened as trust in market efficiency and practices decrease. In particular in the corporate world the massive increase in sectoral concentration has made appeals to the need for internal solidarity to face external (competitive) threats less logical.

The transformational path of the corporate pattern based on these power dynamics would predict that the employees' internal organisations would become more militant, demand more autonomy and then move in the direction of a negotiated bipartite or tripartitism. 'Temporary' workers with high skills, in contrast to permanent workers, have also occasionally been able to 
organise in large corporations as did such workers in the Microsoft corporation (Brophy, 2006). However, if the power dynamics precipitate state intervention this would transform the corporate pattern towards a state corporatist pattern where the nationalisation process changes the goals of the corporation to include that of serving the nation. Such transformations have recently occurred in Latin America (Fizpatrick, DiLullo, 2009).

There is little recent evidence to support such transformative trajectories. In the case of the increase in power of staff associations this may be because of a general loss of confidence in workplace organisations but also loss of confidence that solidarity can prevent dismissals and retrenchments. The weakening of the rationalities has, rather than precipitating greater solidarity, resulted in an increase in the individual response to corporate downsizing and restructuring. Thus disaffection has shown up in a greater incidence of sabotage and whistle blowing (Skarlicki et al., 2008). Whistleblowing in particular has seen a spectacular rise and can easily be correlated with the increased power and presence of corporate power relations (Kaptein, 2011). Such behavior named 'Counter Work Behaviour' has always been part of 'labour relations', although difficult to research and under-reported (Furnham, Siegel, 2012). It is possible, however, this increase may have been due to the increased ease of sabotage because of digitalization and computerization and cyber dependency. The individual rather than the collective response to power relations within the corporate pattern - although here presented as a confirmation that the power relations and rationality are still robust - could also be seen as the precursor to future collective action based on state corporatist regulation.

\section{Conclusion}

The approach used at the level of the social formation indicates the core process by which more and more employees, producers and workers are pushed into subordinate patters of social relations where their power is weakened, and their work and lives unprotected. Most serious analyses would arrive at the same result. The power pattern approach, however, does focus at this level on core relations within and between the corporate pattern thus avoiding an over-emphasis on state and government.

At the level of the specific patterns using secondary research in the four patterns of power it would appear that the enterprise pattern remains stable and sustainable adjustments are being made in the self-employment pattern. This means that the rationalities within them and external to them are still sufficiently powerful to maintain the power relations. In the casual pattern there is weak evidence of an increase in organisations addressing the condition of work and returns which, if it continues, may undercut the general support for fundamentalist and millennialist movements. The corporate pattern does not show an expected transformation towards tripartitism. External linkages between staff associations remain weak or non-existent and grievances against the corporation are manifested by individual acts of sabotage and whistle-blowing.

The purpose of this paper was to show the potential of a different approach to work and labour. If more intensive research was made across all the patterns identified or more depth in key patterns then policies and strategies for change would be enhanced. For example, if it was clear that the internal relations of large corporations were not going to change in favour of an internal monitoring or regulating power - as would be the case of an externally linked worker organisation then it is even clearer that regulatory power would have to be organised externally. Likewise, in the 
casual pattern, the beginnings of an organisational potential amongst casual and precarious workers may reduce the current appeal of abstract fundamentalist and millennialist movements with important implications for local and global politics.

\section{BIBLIOGRAPHY}

Aristotle. The Politics of Aristotle. Translated by E. Barker. (2009) Oxford: Oxford University Press.

Agarwala, R. (2007) 'Resistance and Compliance in the Age of Globalization: Indian Women and Labor Organizations' The ANNALS of the American Academy of Political and Social Science. March vol. 610 no. 1 143-159.

Allison, A. (2012) 'Ordinary Refugees: Social Precarity and Soul in 21st Century Japan' Anthropological Quarterly. 85 (2): 345-370.

Bakker, I. and Gill, S. (2003) (eds.) Power Production and Social Reproduction. London: Palgrave.

Bevir, M. (1999) 'Foucault, Power and Institutions’ Political Studies. 40(7):345-259.

Brophy, E. (2006) 'System Error: Labour Precarity and Collective Organizing at Microsoft' Canadian Journal of Communication. 31(2) [Online] Available at http://www.cjconline.ca/index.php/journal [Accessed: 6 April 2014].

Burawoy, M. (1987) 'The Limits of Wright Analytical Marxist and an Alternative' Berkely Journal of Sociology 23,25 as quoted in Agger, B. (1992) The Discourse of Domination: From Frankfurt School to Postmodernism. Evanston, IL: Northwestern University Press.

Choi, H.-L. and Mattoni, A. (2010), 'The Contentious Field of Precarious Work In Italy: Political Actors, Strategies and Coalitions'. Working USA. 13: 213-243.

Cohen, S. (2003) "Alienation and Globalization in Morocco: Addressing the Social and Political Impact of Market Integration’ Comparative Studies in Society and History. 45(1):168-189.

Cooney, M (2009) 'Ethnic Conflict without Ethic groups: a study in pure sociology' British Journal of Sociology. 60(3):473-492.

Cox, R. (1971) 'Approaches to the Futurology of Industrial Relations', International Institute of Labour Studies Bulletin. 8:139-164.

Cox, R. (1987) Production, Power, and World Order: Social Forces in the Making of History New York: Columbia. 
Cox, R., Harrod, J., et al. (1972) Future Industrial relations: An Interim Report. Geneva International Institute of Labour Studies.

Davies, M. (2006) 'The Public Spheres of Unprotected Workers' in. Ryner, M and Davies M. (eds.) (2006) Poverty and the Production of World Politics: Unprotected Workers in the Global Political Economy. London: Palgrave, pp. 89-113.

Dufour, C., A. Hege, S. Murhem, W. Rudolph et W. Wassermann (2006) Les relations sociales dans les petites entreprises: une comparaison France, Suède, Allemagne. Bruxelles: PIE-Peter Lang.

Dufour, M. and Orhangazi, O. (2007) 'The 2000-2001 Financial Crisis in Turkey: A Crisis for Whom? Review of Political Economy. (2009) 21(1): 101-122.

Fitzpatrick W. and DiLullo, S. (2009) 'Seizure: Government and the Nationalisation of Corporate Assets' Competition Forum. 20097 (2) 1-15.

Foucault, M. (1977) Discipline and Punish: The Birth of the Prison. New York: Random House.

Foucault, M. (1980) Power/Knowledge: Selected Interviews and Other Writings. 1972-1977 (ed. C. Gordon) London: Harvester.

Furnham, A and Siegel, E. (2012) 'Reactions to Organizational Injustice: Counter Work Behaviours and the Insider Threat' in E. Kals and J. Maes (eds.) Justice and Conflicts. New York: Springer, pp. 199-217.

Goldin, L. Rosenbaum, B. and Eggleston, S. (2006), 'Women's Participation in Non-Government Organizations: Implications for Poverty Reduction in Precarious Settlements of Guatemala City' City \& Society. 18: 260-287.

Harrod, J. (1972) Trade Union Foreign Policy: British and American Trade Unions in Jamaica. London: Macmillan.

Harrod, J. (1987) Power, Production and the Unprotected Worker. New York: Columbia University Press.

Harrod, J. (1994) Labour and Third World Debt. Brussels: ICEM.

Harrod, J. (1999) 'The End of Opposition?: Market Power as a Rationality (or Diverting the Egalitarian Neurological Imperative?)' Paper presented at the Annual Convention, International Studies Association, pp. 10 [Online] Available at www.ciaonet.org/isa/har01 [Accessed: 6 April 2014].

Harrod, J. (2001) 'Global Realism: Unmasking Power in the International Political Economy' in Wyn-Jones R. (eds.) Critical Theory in World Politics. London: Reiner. 
Harrod, J. (2003) 'The New Politics of Economic and Social Rights' in Arts, K. and Mihyo, P. Responding to the Human Rights Deficit. The Hague: Kluwer, pp. 61-71.

Harrod, J. (2004) 'Global Unions: Constraints in an Age of the Politics of the Underclass' in Unfried, B. and van der Linden, M. Labor and New Social Movements. Wein: ITH, pp. 91102.

Harrod, J. (2006) 'The Century of the Corporation' in May C. (ed.) Global Corporate Power. London: Lynne Rienner, pp. 23-46.

Harrod, J. (2008) 'The International Labour Organisation and the World Labour Force: From 'Peoples of the World' to 'Informal Sector' [Online] Available at http://www.scribd.com/ doc/2389635/The-International-Labour-Organisation-and-the-World-Labour-Force-FromPeoples-of-the-World-to-Informal-Sector.

Harrod, J. (2011) 'Global Weirmarism: Or Why the Centre Cannot Hold', [Online] Available at www.jeffreyharrod.blogspot.nl.

International Labour Office (ILO) (1972): Employment, Incomes and Equality: a strategy for increasing productive employment in Kenya. Geneva: ILO.

ILO (2010) Global Employment Trends 2010. [Online] Available at http://apirnet.ilo.org/ resources/global-employment-trends-january-2010/ [Accessed: 6 April 2014].

ILO (2012) [Online] Available at http://www.ilo.org/global/topics/forced-labour/lang--en/index.htm [Accessed: 3 February 2014].

ILO/IILS (2012) World of Work Report 2012: Better Jobs for a Better Economy. Geneva: ILO/International Institute for Labour Studies.

Kaptein, M. (2011) 'From Inaction to External Whistleblowing: The Influence of the Ethical Culture of Organizations on Employee Responses to Observed Wrongdoing' Journal of Business Ethics. 98 (3):513-5300.

Lindell, I. (2010) Africa's informal workers: Collective agency, alliances and transnational organizing in urban Africa. London: Zed Books.

Mcdowell, L. Batnitzky, A. and Dyer, S. (2009), 'Precarious Work and Economic Migration: Emerging Immigrant Divisions of Labour in Greater London's Service Sector' International Journal of Urban and Regional Research. 33: 3-25.

Mansbridge, M. and Morris, A, (2001) (eds.) Oppositional Consciousness: The Subjective Roots of Social Protest. Chicago: Chicago University Press. 
Nitzan, J. and Bicchler, S. (2009) Capital as Power: A Study in Order and Creorder. London: Routledge.

Milla, J., Congregado, E., Raman, C. (2009) 'Employers vs. Own-Account Workers: Success and Failure', [Online] Available at http://www.uhu.es/emilio.congregado/materiales/employers persistence.pdf [Accessed: 6 April 2014].

Randels, G. Jr. (2001) 'Loyalty, Corporations, and Community' Business Ethics Quarterly. 11(1): 27-39.

Ryner, M. (2002) Capitalist Restructuring, Globalisation and the Third Way. London: Routledge.

Ryner, M. (2006) 'Workers of the World...: the 'Economic Corporate Moment' of Contemporary World Politics' in Ryner, M. and Davies, M. (eds.) Poverty and the Production of World Politics: Unprotected Workers in the Global Political Economy. London: Palgrave, pp. 62-83.

Ryner, M. and Davies, M. (eds.) (2006) Poverty and the Production of World Politics: Unprotected Workers in the Global Political Economy. London: Palgrave.

Skarlicki, D., van Jaarsveld, D., and Walker, D. (2008) 'Getting even for customer mistreatment: The role of moral identity in the relationship between customer interpersonal injustice and employee sabotage' Journal of Applied Psychology. 93(6):1335-1347.

Townley, B. (1993) 'Foucault, Power/Knowledge, and its Relevance for Human Resource Management 'Academy of Management Review. 18(3): 518-545.

Vestergaard, J. (2009) Discipline in the Global Economy: International Finance and the end of Impact of Inequality: How to Make Sick Societies Healthier. London: Routledge.

WordBank (2014) [Online] Available at http://data.worldbank.org/indicator/SL.TLF.TOTL. IN/countries/1W?display=graph [Accessed: 6 April 2014].

\section{BIOGRAPHICAL NOTE}

JEFFREY HARROD is a writer and essayist and supervises research at the University of Amsterdam. He graduated in international law at UCL London and holds a PhD from the University of Geneva. His publications and online material relevant here are Power, Production and the Unprotected Worker (Columbia UP 1987); 'The Global Poor and Global Politics: Neo-materialism and the Sources of Political Action' in Davis and Ryner (Palgrave 2006); the 16 lecture on-line course 'Global Political Economy: How the World Works'; and essays on 'Global Weirmarism: Or why the Centre Cannot Hold' and 'Corporatism: The 21st Century Political Economic System', at www.jeffreyharrod.eu. [email: J.Harrod@uva.nl] 